\title{
Research on British and American Pronunciation Differences in College English Phonetics Courses
}

\author{
Xiaoyi LIU \\ Foreign Language Department of Jilin Business and Technology College \\ Changchun City, China, \\ Email:lihongbin1975@163.com
}

\begin{abstract}
With the deepening of new curriculum reform, English is introduced into primary school, however, in high school education and compulsory education stage, although English teaching focuses on listening, speaking, reading and writing, there is not a clear distinction of British English and American English, which is fortunately attached great importance to in university. This paper intends to study the differences between British and American pronunciation teaching in college English phonetics classes. On the one hand, it can help students have a comprehensive understanding of the diversity of English pronunciation and improve students' listening and speaking skills of the English language; on the other hand, it aims to discuss the necessity and strategies of differential teaching in college English phonetics class.
\end{abstract}

Keywords-College English; Phonetics class; British and American pronunciation differences; Teaching research

\section{INTRODUCTION}

The practical goal of college English phonetics class is to help students master and use of the English pronunciation and intonation skillfully so as to improve their English level and strengthen their English communication ability. In order to achieve this goal, English phonetics class usually introduces the relevant theoretical knowledge of phonetics and phonology and makes the students master segmental features and supra-segmental features through pronunciation correction training (including the vowels and consonants) and training of coherent flow(including stress, even read, weak pronunciation, rhythm, intonation, etc.) supplemented by a large number of practice. It is important to note that Received Pronunciation (RP) and General American (GA), as two influential modes of English phonetics, have significant differences in segmental feature and suprasegmental features, which is unfortunately paid little attention to or even totally ignored in the domestic university phonetic teaching materials at present. Is it necessary to refer to the difference between RP and GA in English phonetics course in colleges and universities? If necessary, how to implement it? What principles should be followed in the process of implementation? This article will revolve around the above three questions and carry on the preliminary discussion on RP and GA differences in English phonetics course in colleges and universities. ${ }^{[1]}$

\section{THE IMPORTANCE OF TEACHING RP AND GA DIFFERENCES IN ENGLISH PHONETICS}

In a sense, English teachers in the process of phonetic teaching should enable their students to learn the concept of RP and GA differences appropriately and penetrate specific content into phonetic class so as to effectively help the students learn to distinguish RP and GA differences and then grasp the main point, which is of great practical significance in college English class. In terms of English phonetic teaching on RP and GA differences, scholars both at home and abroad conducted researches in the early years and held different viewpoints about it.

In 1886, International Phonetic Association was established to be the beginning of phonetic teaching standardization. In the later researches after nearly a century, all kind of teaching methods, whether direct method or audio lingual teaching, received native English pronunciation as the standard. But, in the 1980s, Communicative Approach had a difference with the traditional teaching method, which enabled the "intelligibility" of phonetics to be the teaching goal and brought hope to the development of American English. Affected by this, scholars generally opposed stereotyped native model. In view of flexible communication, they believed RP and GA as two of the many English accents, just like China's mandarin, Cantonese, Hokkien dialect and Hakka dialect, which needn't to be strictly controlled and corrected to be pure accent, therefore, RP is not enough to become a universal standard among all English accents. They focus on the intelligibility instead of RP and GA difference. Based on intelligibility, some foreign scholars principled minimum intelligibility and proposed to combine RP and GA. However, in China, scholars hold different views. They attach more importance to RP of native English speakers and regard its English phonetic annotations as teaching target, so as to hope that through combination of theory and practice, Chinese students' pronunciation standards can be improved. ${ }^{[2]}$ In order to reduce students' bewilderment on the differences between RP and GA and help students master the standard English pronunciation, scholars agree to conduct GA teaching on the basis of traditional teaching model. 


\section{IMPLEMENTATION STRATEGIES}

The so-called RP and GA differential teaching in this paper doesn't mean to separate RP and GA difference from the traditional teaching content, or exaggerate and emphasize the differences between British and American pronunciation, but requires phonetic teachers to penetrate $\mathrm{RP}$ and GA difference in the teaching process and make explanation and demonstration of British and American pronunciation differences, so as to enable the students to understand the diversity of English pronunciation and improve students' listening and speaking skills of English language. In the teaching process of British and American pronunciation differences, the teaching units should make a preparatory efforts in textbook compilation and faculty training and teachers should involve in curriculum provision and teaching arrangement combined with the actual situation, so as to make a proper balance of theory and practice and combine pronunciation correction teaching and coherent speech practice. Generally speaking, teachers in the teaching process of British and American pronunciation difference should focus on the following three points:

\section{A. Elaborate the RP and GA difference in sound class and tone quality}

In domestic phonetic teaching class, consonant is often recognized as the focus of teaching due to the difficulty and complexity in its place and manner of articulation, which is difficult for students to understand and master, so it is necessary to comprehend consonant in theory and practice. In view of British and American phonetic differences, British and American phonetic difference in vowels are more obvious than that in consonants, so in order to strengthen the British and American phonetic difference teaching, teachers must focus on the vowel difference of RP and GA in sound class and tone quality.

In general, the vowel difference of RP and GA is mainly embodied in sound class and tone quality. In terms of sound class, GA lacks of a back vowel $/ Q /$ and three centring diphthong /eə/, /iə/, /uə/, which are respectively pronounced as /ir/,/er/,/ur/; In terms of tone quality, in addition to individual vowels (such as $/ \mathrm{i}: /, / \mathrm{i} /, / \mathrm{u} /$ ), the other vowels have obvious differences in tongue, mouth and length, such as /e/ is pronounced with a lower tongue and a wider mouth opening in GA than in RP, mouth slightly wider, while /eə/ is pronounced in a higher tongue and a narrower mouth opening position in GA than in RP.

\section{B. Clarify RP and GA difference at supra-segmental level}

RP and GA difference at supra-segmental level refers to two characteristics: intonation and stress, in which intonation can reflect the RP and GA difference to the largest extent. In the current teaching of intonation, the teacher is mainly to introduce the types and functions of intonation. But in view of RP and GA difference, there is a considerable difference in intonation. GA sounds more rhythmical to compare with RP, but if teachers let the students imitate, it is often difficult for them to catch the point. Therefore, teachers are supposed to show the difference in intonation and stress between GA and RP for students and create opportunities for them to imitate.

\section{Introduce diversified phonetics}

Although English phonetic teaching is based on the difference between GA and RP in phonemes and suprasegment feature, its starting point and purpose is to instill the concept of the diversity of English phonetics to students. In the interpretation of the RP and GA differences, teachers need to tell their students timely that English speech patterns in the world are not only RP and GA, there are Australian English, Indian English and Singapore English variants, and various differences even exist in the Anglo-American countries.

So in teaching process of RP and GA differences, teachers had better show their students characteristics of different English accents through audio-visual material. In addition, teacher should introduce students to the diversification of speech standards. In short, it is necessary to introduce diversified phonetics in teaching process of RP and GA difference and encourage students to choose their favorite accent according to their preferences and the actual needs.

\section{PRINCIPLES IN TEACHING RP AND GA DIFFERENCE}

English teachers should follow the following principles in the process of teaching RP and GA differences:

\section{A. Make full use of phonetic theory to guide teaching}

English teachers should make the best of phonetics and phonology theory to guide teaching practice. In recent years, there is a tendency to ignore the theoretical knowledge in phonetic teaching. Therefore, if students ask RP and GA differences, some teachers will advise students to watch the foreign films and TV programs, thinking that as long as the students listen more, they will understand English pronunciation characteristic sooner or later. Admittedly, a few students have better language talent and stronger imitate ability, they can therefore grasp the differences in British and American pronunciation independently, but for quite a few students with a poor acquisition and imitation ability, teachers must combine the international phonetic alphabet, pronunciation organs flank and front figure, tongue bitmaps and other visual tools, explain the difference of British and American pronunciation theoretically as to guide the students to carry on the relevant practice of pronunciation correction and coherent speech, cultivate students' ability of self-correction and effectively help the students master the difference between British and American pronunciation. ${ }^{[3]}$

\section{B. Assist teaching with personal experience}

English teachers not only should have a good phonological competence, but also must understand the specific phonetic manner and steps, on this basis, they are able to explain the difficulty in pronunciation skillfully, describe the pronunciation skill with the simplest description, and form a maneuverable method to be applied to teaching practice 


\section{Refuse students to speak Chinglish}

Though English phonetic patterns throughout the world are becoming more and more diversified, RP and GA are also constantly bombarded with the challenge of the new standards, phonetics teachers should not encourage students to speak the so-called "Chinglish" (Chinese-style English). Many people think that no matter Chinese students learn British accent or American accent, they finally speak Chinglish. This makes sense to some degree. However, Chinese teachers can't let students speak terrible Chinglish in order to accommodate students because negative transfer of mother language.

\section{CONCLUSION}

In a word, it is not only necessary but also feasible to conduct phonetics teaching on RP and GA differences. The purpose is not to promote relative merits and specify pronunciation standard for students, instead, it is to encourage students to figure out the nature of language diversification through the phenomenon of British and
American pronunciation differences and enable students to find a foothold of their own cultural identity in the globalized world so as to cultivate their interest in the English language itself and strengthen their English communication ability. Therefore, it is an important development goal of college English phonetic teaching to strengthen the differential teaching of British and American pronunciation differences in the future.

\section{REFERENCE}

[1] Celce, Murcia, Marianne, Donna Brinton, and Janet M. Good win. Teaching Pronunciation: A Reference for Teachers of English to Speakers of Other Languages[ M]. Cambridge: Cambridge University Press, 1996:2-11.

[2] Jenkins, Jennifer. Research in Teaching pronunciation and intonation[J]. Review of Applied Linguistics. 2004,24:109 -25.

[3] Cui Haijian, Discussion on GA and RP difference [J]. Foreign Language Teaching and Research, 1993 (1):27 -29 